\title{
Challenges to address climate adaptation actions in coastal New England - insights from a web survey
}

\author{
Desafios para endereçar ações de adaptação climática na costa \\ de New England - insights de uma pesquisa
}

\section{Desafíos para abordar las acciones de adaptación climática en la costa de New England: ideas obtenidas de una encuesta}

\author{
Ana Mesquita-Emlinger ${ }^{1}$ \\ Salem State University, USA
}

\begin{abstract}
Coastal communities all over the world are experiencing unprecedented alterations from climate change. Unlike what most people would guess, coastal communities have not advanced much in their preparedness for a climate that is changing fast, despite their extensive exposure to climate hazards. If not true worldwide, at least that is what is happening in the majority of small and medium communities in the coast of New England, in the Northeast of US. This article explores data collected in a web survey conducted with city officials of coastal communities in the states of Connecticut, Rhode Island, Massachusetts, New Hampshire and Maine, aiming to verify barriers to address climate change adaptation at the local level. The results of the survey showed many similarities between the challenges experienced by these small coastal communities. We suggest that, in presenting the main themes of the research, including special attention to the barriers encountered, this knowledge can contribute to the creation of a more climate-friendly region, thus helping to design and implement future climate change policies at the local level.
\end{abstract}

Keywords: climate change; adaptation; coastal communities; urban planning

1 Ph.D. in Regional Planning by the University of Massachusetts Amherst. Assistant Professor in the Department of Geography, Salem State University, USA. E-mail: aemlinger@salemstate.edu

Este artículo corresponde a la ponencia presentada en el 35th Conference of Latin American Geographers realizada en San José, Costa Rica del 20 al 22 de mayo del 2018. 


\begin{abstract}
Resumo
Comunidades costeiras de todo o mundo estão experimentando alterações sem precedentes devido a mudança climática. Ao contrário do que a maioria das pessoas imaginaria, as comunidades costeiras não tem avançado muito em sua preparação para um clima que está mudando rapidamente, apesar de sua ampla exposição aos riscos climáticos. Se não é verdade em todo o mundo, pelo menos é o que está acontecendo na maioria das pequenas e médias comunidades da costa da Nova Inglaterra, no nordeste dos EUA. Este artigo explora dados de uma pesquisa realizada com autoridades municipais de comunidades costeiras nos estados de Connecticut, Rhode Island, Massachusetts, New Hampshire e Maine, com o objetivo de verificar as barreiras para abordar a adaptação às mudanças climáticas em nível local. Os resultados da pesquisa mostraram muitas semelhanças entre os desafios experimentados por essas pequenas comunidades costeiras. Sugerimos que, ao apresentarmos os principais temas decorrentes da pesquisa, incluindo atenção especial às barreiras encontradas, esse conhecimento pode contribuir para a criação de uma região mais adaptada ao clima, podendo assim ajudar na elaboração e implementação de políticas futuras de mudança climática em nível local.
\end{abstract}

Palavras-chave: Mudanças climáticas; adaptação; comunidades costeiras; planejamento urbano

\title{
1. Introduction
}

Climate science is providing an increasingly sophisticated picture of possible climate alteration in future decades, and for coastal zones in particular, the potential consequences are a cause for mounting concern.

Anthropogenic or human-driven climate change is now fully established in the scientific literature, as well as adaptation to these impacts as necessary and complementary to mitigation efforts (IPCC, 2007; Holdren, 2008; Moser and Boykoff, 2013). However, planning for climate change adaptation efforts, in practice, is still in a relatively nascent stage (Adger, Arnell \& Tompkins, 2005; Measham et al., 2011; Bierbaun et al., 2012, Schectman and Brady, 2013). Climate initiatives and adaptation plans are still in early phases of development (Preston, Westaway \& Yuen, 2011; Carmin and Dodman, 2013). The growing urgency associated with responding to climate risk has elevated climate adaptation on policy agendas across a broad array of institutions and governance networks (Swart et al. 2009). While adaptation is increasingly recognized as an important climate risk management strategy, and on-the-ground adaptation planning activity is becoming commonplace, local officials from coastal communities lack guidance on what to aim for, and how to judge if their initiatives were successful or not (Moser \& Boykoff, 2013).

This study examines how small and mid-sized communities in coastal Connecticut, Rhode Island, Massachusetts, New Hampshire and Maine have addressed climatic impacts in their local planning, and the biggest barriers they have encountered in this process. 
In a previous study by the author (see Hamin, Gurran \& Emlinger, 2014), based on interviews with planners of small coastal Massachusetts communities, data shows that smaller communities in this region have only attempted very limited adaptation efforts. While the literature suggests that there are discrete barriers to adopting climate adaptation policies or activities, most respondents stressed that these barriers are extremely interconnected.

Adaptation researchers have generally assumed lower vulnerability and greater adaptive capacity in developed countries than in developing countries and thus have focused more research in the latter (Moser and Ekstrom, 2010; Adger at al., 2005). However, climatic events of recent years striking high income nations have led to a questioning of the real ability of these nations to adapt to climate change (Moser and Ekstrom, 2010).

Despite the high visibility that adaptation has on the global policy agenda and the imperative for cities to initiate action, relatively few have made concerted efforts to develop dedicated adaptation plans or to set adaptation initiatives in motion (Carmin, Anguelovski \& Roberts, 2012).

\section{Background}

New England (NE) has been explored in other relevant studies in climate adaptation, and examined in very diverse aspects (For example: Schechtman \& Brady, 2013; Carmin et al., 2012; Moser, Kasperson, Yohe \& Agyman, 2008; Shi, Chu \& Debats, 2015). Schechtman \& Brady (2013) developed a research on community-level coastal flood management and climate change adaptation best practices throughout the North Atlantic region (from Virginia to Maine), aiming to identify and collate cost-effective adaptation projects implemented at the municipal level, providing best practice information to assist with ongoing adaptation outreach.

Carmin's research program was designed to advance knowledge of what motivates cities to pursue new policy agendas and to advance policy and professional understanding of urban climate adaptation planning and implementation. The study was based on four data collection methods: case studies of upper, upper middle, and lower middle income countries, in-depth, comparative analysis of cities in the US and Japan, focus groups and interviews with urban adaptation leaders and a global survey conducted in partnership with ICLEI - Local Governments for Sustainability. Some New England coastal communities were included in the study. 
The study conducted by Moser et al. (2008), after a preliminary assessment of the region's adaptive capacity, suggest that the Northeast is potentially quite vulnerable to experiencing negative impacts from climate variability and change. At the same time, they highlight the importance of recognizing that vulnerability and adaptive capacity are not uniform. Both vary across the region's economic sectors, ecological environments, and subsections of the population.

In their study, Shi, Chu \& Debats (2015) demonstrated the degree to which strong political leadership, high municipal expenditures, and perceptions that the climate is already changing are associated with adaptation planning among environmentally progressive cities. Their survey used ICLEI's network of 1,200 municipalities in 86 countries as a sampling frame to describe global urban adaptation trends. Among them, we can find a few coastal communities of New England.

Existing research has also found that little pressure on local governments on adaptation planning due to a lack of federal and state policies end up also contributing for the slow advancement in climate adaptation planning (Amudsen, Berglund \& Westskog, 2010; Measham et al., 2011). Cities ability to plan for climate adaptation seems to depend on the existence and enforcement of state policies. Although some earlier adopter cities have initiated adaptation planning without state mandates, less progressive cities are unlikely to do so (Bedsworth and Hanak, 2010; Shi et al., 2015).

\section{Study area}

New England is a northeasterly region of the United States comprising the states of Maine (ME), Vermont (VT), New Hampshire (NH), Massachusetts (MA), Connecticut (CT) and Rhode Island (RI) (Figure 1). 

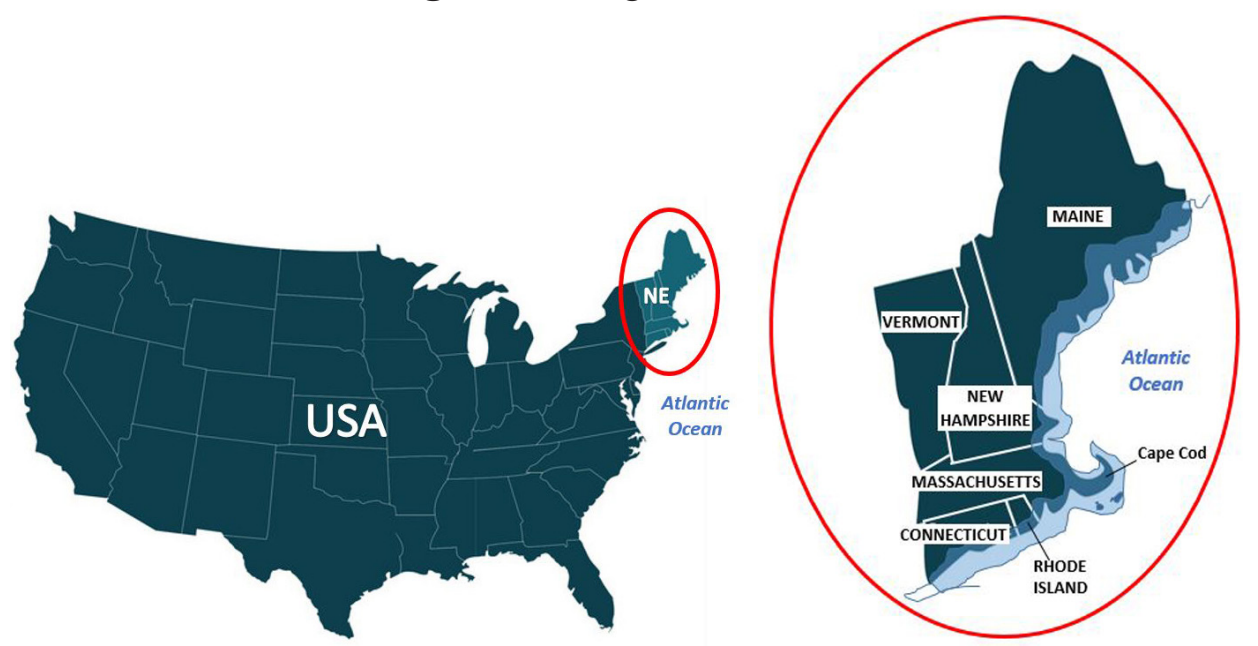

Source: Organized by the author.

Coastal New England, formed by all the States, but Vermont, on the Atlantic seaboard, is highly vulnerable to anticipated climate change. All the 250 Atlantic Ocean coastal communities in the region were initially selected for this study. Since we were intending to focus in small and midsized communities, the cities with more than 150.000 habitants - Boston (MA) and Providence (RI) - were not included.

\section{Research Design and Methodology}

This study examines data collected from a web based survey of NE coastal local government representatives. Local planning units in New England, as in many parts of the United States, possess considerable power in making the day-to-day land use decisions (Ryan, 2006). All recipients were contacted by email and provided a link to complete the survey online from November of 2015 to January 2016. In general, respondents were asked to identify the biggest challenges in the attempt to address climatic impacts in their local planning, the types of initiatives they were planning to start or that they have taken so far and what they needed to start moving forward.

Since regional trends can mask the unique challenges faced within states, chi-square tests of independence for two-way tables were conducted on some items to investigate whether distributions of categorical variables 
such as actions already taken by the communities or actions that they intend to start, major challenges encountered by them, status of climate adaptation and other variables differ from one another regarding the State communities are located, their number of habitants, among others. We inferred that the chi-square result is statistically significant when $\mathrm{p}<0.05$.

\section{Response Rate (RR)}

Our overall response rate was of $61.95 \%$. Off the 226 emails sent with the link for the survey, 155 respondents opened the survey; 153 accepted the conditions expressed in the Consent form, 140 of them answered at least one survey question, and 121 completed the survey. These 121 were considered valid.

New England small and medium-sized coastal communities were, for the purpose of this study, named "target population". Massachusetts has 77 communities in the target population, however, one of these communities does not have a website. So, the sample in MA was reduced to 76 communities. A total of 63 completed the survey, for a RR in MA of $82.89 \%$. From the 108 categorized as our target population in Maine, 21 did not have a website. The sample in Maine was reduced to 87 communities. A total of 40 out of the 87 completed the survey, for a RR in ME of $45.98 \%$. All the 36 target population in Connecticut have websites providing email contact of their personnel. A total of 17 out of the 36 completed the survey, for a RR in CT of $47.22 \%$. For Rhode Island we also found information about the 20 communities - 16 out of the 20 completed the survey, for a RR in RI of $80 \%$. And finally New Hampshire, the state with the smallest shore line, with only 7 communities in the range of our population, was contacted. A total of 4 out the 7 completed the survey, for a RR in $\mathrm{NH}$ of $57.14 \%$ (Table 1 ). 
Ana Mesquita-Emlinger. Challenges to address climate adaptation actions in coastal New England - insights from a web survey

Table 1 - Sampling and Response Rate (RR)

\begin{tabular}{|l|c|c|c|c|}
\hline \multicolumn{1}{|c|}{ State } & $\begin{array}{c}\text { Target } \\
\text { Population (TP) }\end{array}$ & $\begin{array}{c}\text { Surveys Sent } \\
\text { (sample) }\end{array}$ & $\begin{array}{c}\text { Surveys } \\
\text { Returned }\end{array}$ & $\begin{array}{c}\text { Response Rate } \\
\text { (RR) }\end{array}$ \\
\hline Massachusetts & 77 & 76 & 63 & $82.89 \%$ \\
\hline Rhode Island & 20 & 20 & 16 & $80 \%$ \\
\hline New Hampshire & 7 & 7 & 4 & $57.14 \%$ \\
\hline Connecticut & 36 & 36 & 17 & $47.22 \%$ \\
\hline Maine & 108 & 87 & 40 & $45.98 \%$ \\
\hline Total & $\mathbf{2 4 8}$ & $\mathbf{2 2 6}$ & $\mathbf{1 4 0}$ & $\mathbf{6 1 . 9 5 \%}$ \\
\hline
\end{tabular}

Source: Elaborated by the author (2018).

\section{Results}

The results of the survey presented many similarities among these communities. Graphic 1 summarizes the main combined findings of the survey. It shows the major challenges these smaller coastal NE communities experience in their adaptation planning, preferred steps for actions, what they need to move forward in their climate planning and source for information and guidance considered reliable.

Graphic 1 - Three top results for the main questions in the study.

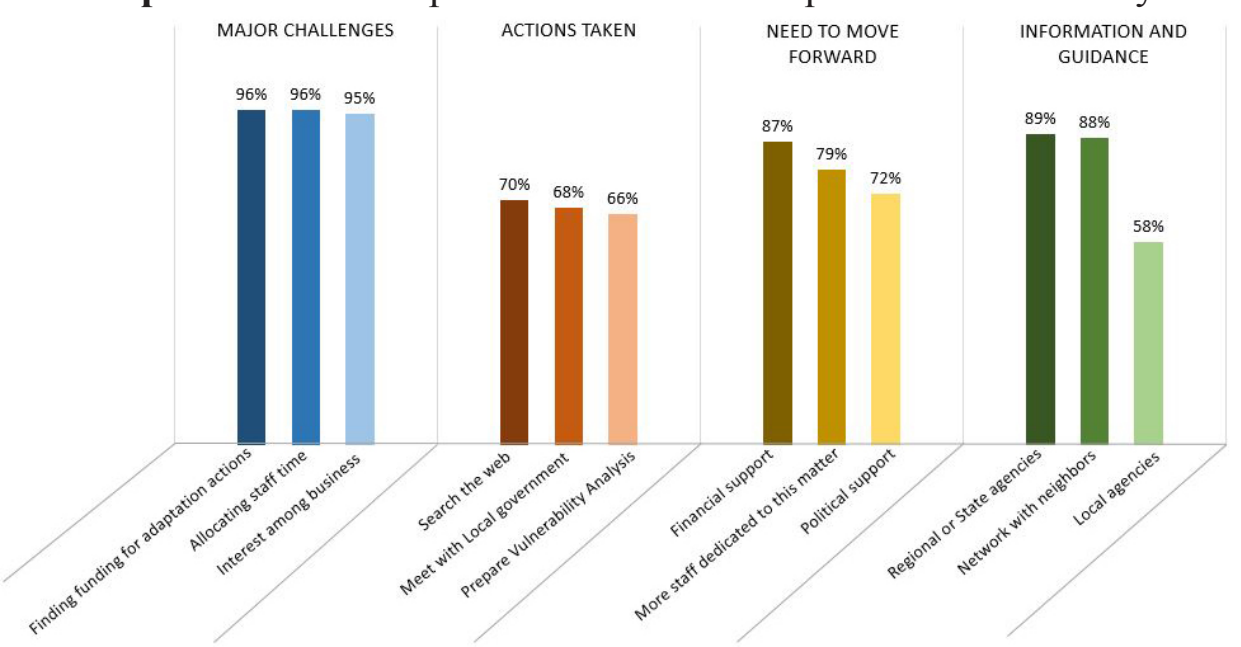

Source: Elaborated by the author (2018). 
The high rates of responses emerge from the graphic. The three main challenges, for instance, are encountered by more than $90 \%$ of communities. These rates indicate that, in general, problems faced by these small and medium coastal communities are identical, despite the state where these communities are located, their size of population or even presence or lack of particular state policies.

Communities report many challenges as they pursue adaptation planning. Because adaptation can still be considered a new policy arena, many local governments are trying to take actions with limited resources (Carmin et al, 2012). Participants were presented the 13 most common challenges usually faced by communities according to previous study by the author (see Hamin et al., 2014) and extensive search in the literature. It's remarkable that almost $100 \%$ of respondents in all states reported finding funding as their major challenge.

Consistent in the literature, lack of financial support appears to be the most common obstacle that make adaptation less efficient and less effective (Tribbia and Moser, 2008; Moser and Eckstron,2010; Clar et al, 2013; Hamin and Gurran, 2014; Eisenack et al, 2014; Hamin et al, 2014; Shi et al, 2016). Not surprisingly, among our survey respondents finding funding to pay for adaptation action was rated the top major challenge when trying to address climate adaptation, at $82.5 \%$ of the communities (99 indications; $\mathrm{n}=120$ ). Allocating staff time to work on adaptation was rated as the second major challenge $(66.4 \%, \mathrm{n}=122)$.

We expected that there would be some relationship between communities' ability to find funding for adaptation and the State in which they are located (Graphic 2a, called "case 1") or their size of population (Graphic $2 \mathrm{~b}$, called "case 2 "). 
Ana Mesquita-Emlinger. Challenges to address climate adaptation actions in coastal New England - insights from a web survey

Graphic 2a - Number of towns where finding funding is a challenge by State ("case 1")

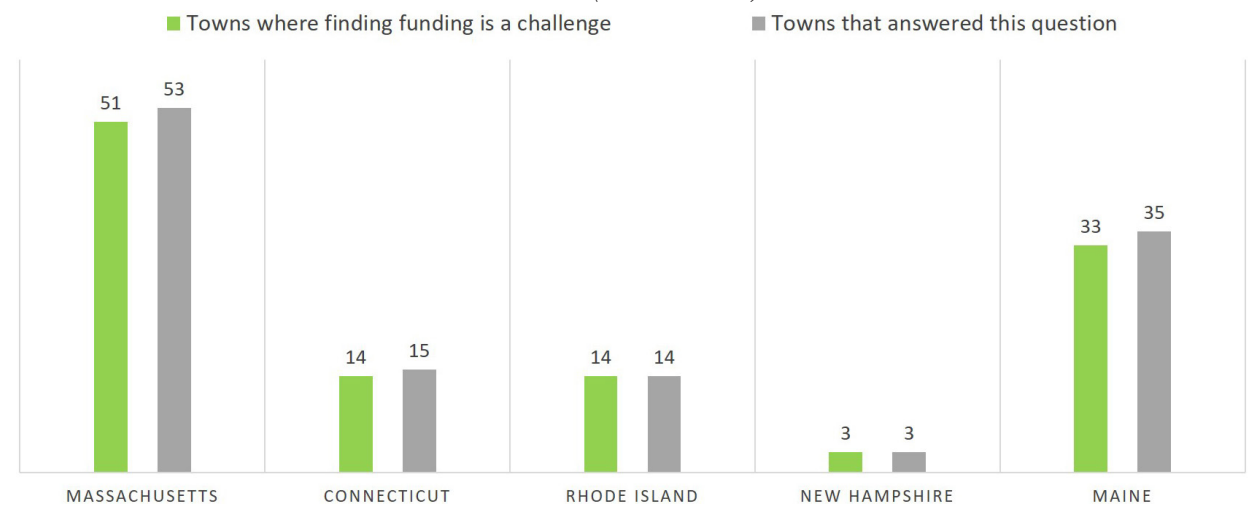

Source: Prepared by the author (2018).

To test this, we ran a chi-square test. In both cases 1 and 2, the non-significant p-values mean that the Chi-square test was not able to detect an effect of one variable (state or population size) on the other variable (finding funding), and the results obtained could be due to random chance. It is important to acknowledge that we can still interpret the descriptive results (the percentages), but since the result was non-significant, there is no statistical evidence that the two variables are related. Again, this could be because: a) there really is no relationship between the two variables in the population or $b$ ) the small counts in some cells makes the Chi-square test less able to detect a difference.

When looking at this big barrier and the population size, results show that it impacts all of the communities with less than 1.000 habitants and those between 10.001 and $20.000,95.6 \%$ of those with more than 1.001 and less than $10.000,92.31 \%$ of communities with more than 50.000 habitants and $87.5 \%$ of those between 30.001 and 50.000 habitants. These numbers show a clear trend here - the smaller the community, the more likely there is a financial problem (Graphic 2b). 
Graphic 2b - Number of towns where finding funding is a challenge by Number of Inhabitants ("case 2")

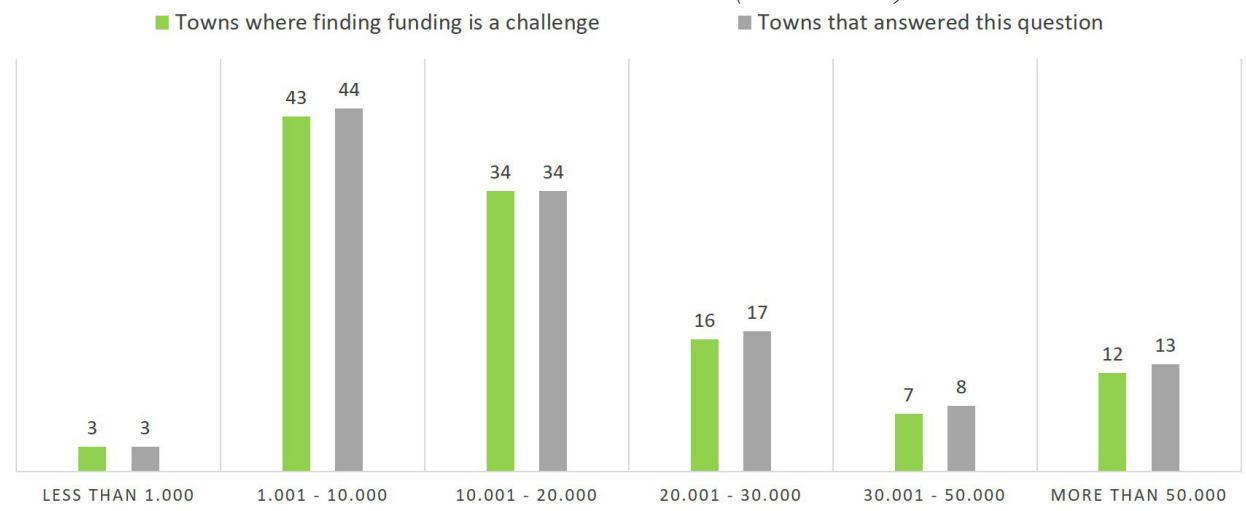

Source: Prepared by the author (2018).

Summarizing, we could infer that the p-value results $(0.95$ in case 1 and 0.83 in case 2) are very reflective of the reality, because combined with this analysis, they show that finding funding for adaptation is a generalized challenge among these municipalities, regardless their size or location. Communities in the area not only lack funding. Allocating staff time to work on adaptation, as mentioned before, was rated as the second biggest challenge faced by them. All the communities in Massachusetts $(n=53)$ and in New Hampshire $(n=4)$ that answered this question suffer the challenge of assigning staff time to dedicate to this matter. In the three other states the situation appears that it might be somewhat better: $93.3 \%$ in Connecticut, $92.9 \%$ in Rhode Island, and $91.7 \%$ in Maine (Graphic 3a). 
Ana Mesquita-Emlinger. Challenges to address climate adaptation actions in coastal New England - insights from a web survey

Graphic 3a - Number of towns experiencing allocating staff time as a challenge by State

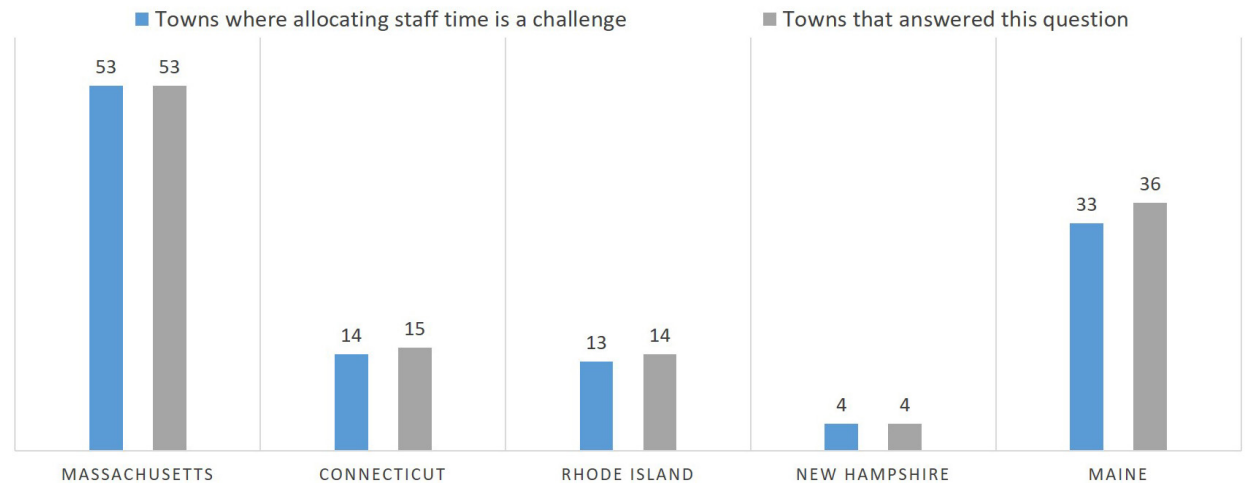

Source: Prepared by the author (2018).

To test this question, the null hypothesis states that there is no influence of the state communities are located in the existence of this challenge. After running a chi-square test, the P-value obtained doesn't find evidence to reject the null hypothesis, just as in the previous cases. Furthermore, Graphic 3a shows clearly that this challenge is spread in practically all the communities that answered the question. In other words, there is no significant relationship based on the state communities are located and the difficulties to allocate staff time to work on adaptation.

One question seems reasonable regarding the size of the community: is it harder for the smallest ones to allocate staff time to work on adaptation? Did the sample provide strong evidence of a relationship here? This could certainly be a possibility, but, again, the $\mathrm{P}$ value was way beyond 0.05 , which means that such relationship does not exist. Results are, somewhat, concerning: $100 \%$ of communities with less than 1.000 habitants, between 10.001 to 20.000 and those in the range from 30.001 to 50.000 struggle with allocating staff time to work on adaptation, and more than $90 \%$ in the rest of population ranges also reported this challenge. Indeed, the non-significant $P$ value (0.48) makes sense, once almost all the communities in every single population range of the survey sample reported struggling with this barrier that is likely to be delaying their local adaptation process (Graphic 3b). 
Graphic 3b - Number of towns experiencing allocating staff time as a challenge by Number of Inhabitants

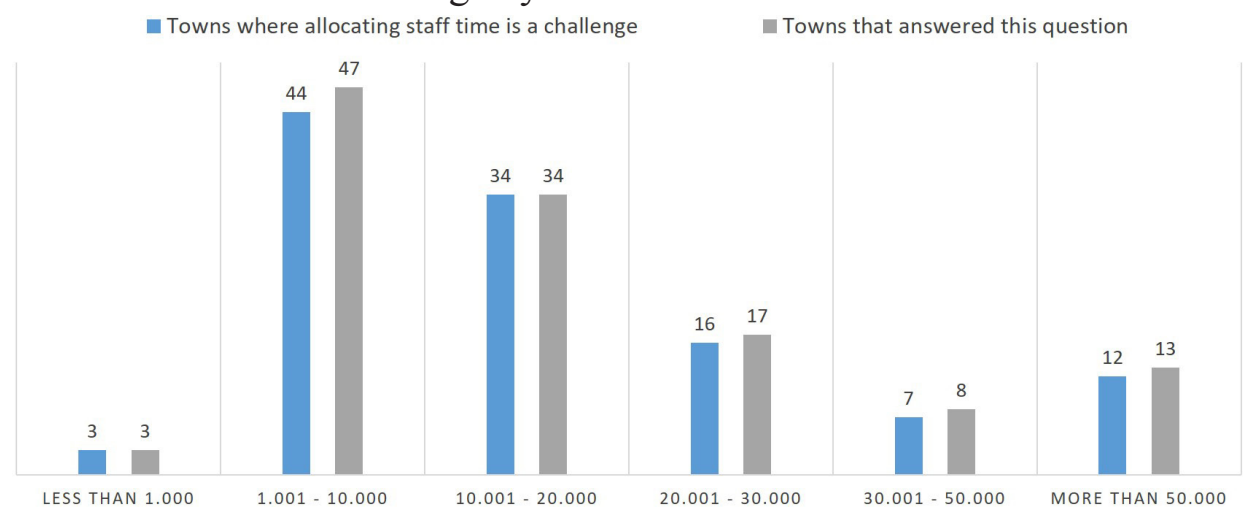

Source: Prepared by the author (2018).

The third barrier that appear to deeply impact these communities is the lack of ability in generating interest in climate adaptation among business. We already know that the state communities are located and their size of population do not seem to exert any influence in finding funding for adaptation (the top challenge) nor in allocating staff time to work on adaptation. We found similar results here as well. Upon running the chi-square test, the result was non-significant, indicating that there is no statistical evidence that the ability to generate interest in adaptation among business and the state they are located are related. Graphics $4 \mathrm{a}$ and $4 \mathrm{~b}$ illustrate the amount of towns that struggle in generating interest among business in each state, in comparison with the number of communities that answered this specific question. 
Ana Mesquita-Emlinger. Challenges to address climate adaptation actions in coastal New England - insights from a web survey

Graphic 4a- Number of towns where generating interest among business is a challenge by State

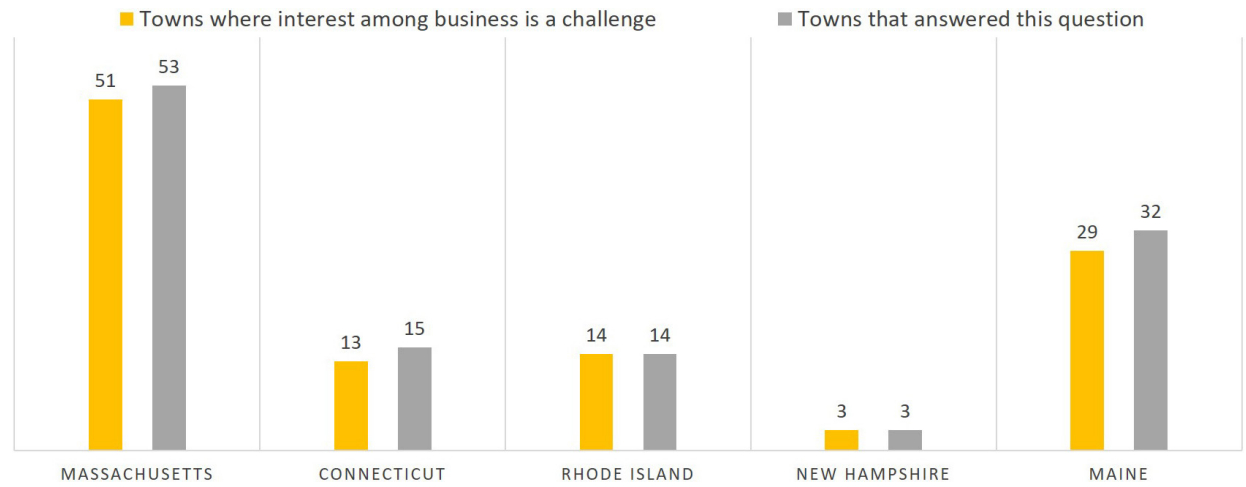

Source: Prepared by the author (2018).

Graphic $4 \mathbf{b}$ - Number of towns where generating interest among business is a challenge by number of inhabitants

Towns where allocating staff time is a challenge

Towns that answered this question

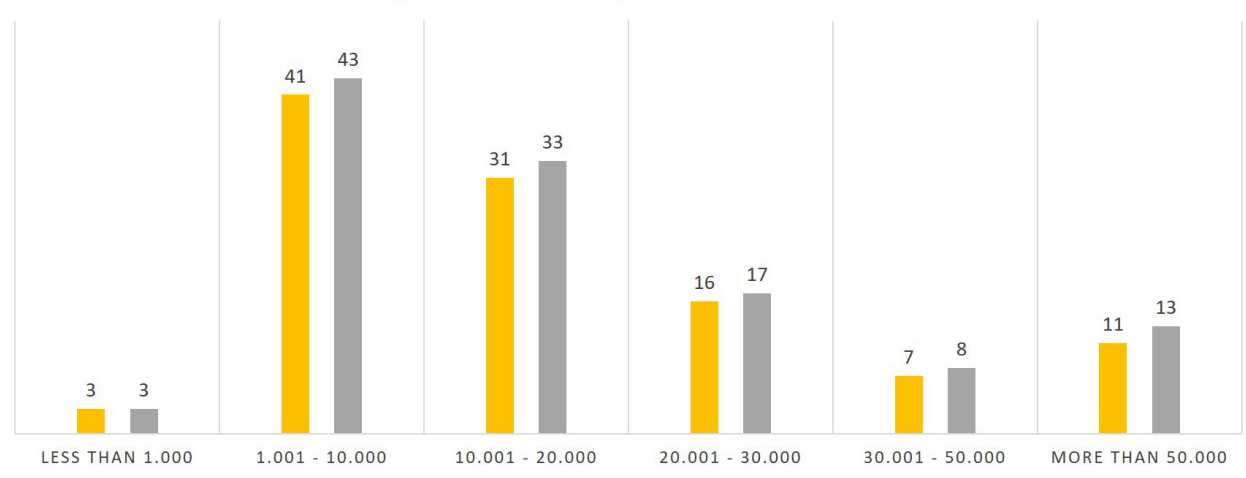

Source: Prepared by the author (2018).

Summarizing, in the cases of the three major challenges mentioned - finding funding, allocating staff time, and generating interest among business - survey results demonstrated that the state or the size of the population did not exert absolutely any influence in increasing or decreasing those challenges. A simple observation of this fact provides basic findings that may be useful to promote understanding of the region. At least, from the analysis of the three top challenges, we come to a conclusion that small and medium coastal communities in New England strive together to fight 
these roadblocks that hinder their ability to be more proactive in planning for climate change adaptation at the local level.

\section{Discussion and Conclusion}

While hundreds of cities around the world are working on mitigation actions, fewer local governments have developed adaptation plans, making climate adaptation planning still a novelty in many places (Blanco, McCarney, Parnell, and Seto, 2011). For this article, we focused our attention in the biggest challenges that these small and mid-sized coastal communities in New England are facing. We propose identifying these barriers as a primary mechanism by which future strategies for the area can be proposed.

Funding and staffing constraints were evident in the study results, representing the two main challenges experienced by these coastal communities. These barriers are highly recognized in the adaptation literature (Tribbia and Moser, 2008; Moser, 2010; Measham et al., 2011; Carmin et al, 2012; Hamin and Gurran, 2014; Hamin et al., 2015; Shi et al., 2016).

Respondents presented considerable agreement among the biggest challenges experienced by them. Because finding funding to pay for adaptation actions was indicated as the top challenge faced by the vast majority of communities, it was not surprising that financial support was rated as what they need the most to start moving forward, as shown in Graphic 1. Only four communities surveyed have a full-time staff member dedicated to the issues of climate adaptation planning, and yet 2 of them pointed "Allocating staff time to work on adaptation" as a challenge when trying to address climate adaptation in their local government.

Just as 'state adaptation planning is in its early stages, so is scholarly inquiry into it', as reflect Ray \& Grannis (2015, p. 21). Studies like this can help us grasp what we know, don't know and need to know (Ford et al., 2011). We naturally do not argue that the study captures all challenges in adaptation actions present in coastal New England. What the work does offer is an indicator - a snapshot of what is happening - that can be used to monitor adaptation overtime. Importantly, examining these challenges offers guide for future research.

We recognize some limitations in the study. Respondents were almost all planners, and thus we are looking at a small slice of a big group of stakeholders. Nevertheless, we believe that information collected in this 
survey can still inform future initiatives. We understand that the results presented are far from being a singular case. Thus, we cautiously view our findings as broadly applicable outside New England, USA, even if the specifics are likely to differ from location to location.

\section{References}

Amundsen, H., Berglund, F., \& Westskog, H. (2010). Overcoming barriers to climate change adaptation-A question of multilevel governance? Environment and Planning C: Government and Policy, 28(2), 276-289.

Adger, W. N., Arnell, N. W., \& Tompkins, E. L. (2005). Successful adaptation to climate change across scales. Global Environmental Change, 15(2), 77-86.

Adger W (2009) Are there social limits to adaptation to climate change? Climate Change 93, 335-54.

Bedsworth, L. W., \& Hanak, E. (2010). Adaptation to climate change: A review of challenges and tradeoffs in six areas. Journal of the American Planning Association, 76(4), 477-495.

Bierbaum, R., Smith, J. B., Lee, A., Blair, M., Carter, L., Chapin, F. S.,(...), Verduzco, L. (2013). A comprehensive review of climate adaptation in the United States: More than before, but less than needed. Mitigation and Adaptation Strategies for Global Change, 18(3), 361-406.

Blanco, H., McCarney, P., Parnell, S., Schmidt, K., and Seto, C. (2011). The role of urban land in climate change. In Climate Change and Cities: First Assessment Report of the Urban Climate Change Research Network, Rosenzweig, C., Solecki, W., Hammer, S. and Mehrotra, S. (eds). Cambridge University Press, Cambridge, UK, 217-248.

Carmin J, Anguelovski I, and Roberts D (2012) Urban Climate Adaptation in the Global South: Planning in an Emerging Policy Domain. Journal of Planning Education and Research 32, 18-32.

Carmin, J., Dodman, D., \& Chu, E. (2013). Urban climate adaptation and leadership (OECD Regional Development Working Papers No. 2013/26). Retrieved from http://www. oecd-ilibrary.org/urban-ruraland-regional-development/ urban-climate-adaptation-andleadership_5k3ttg88w $8 \mathrm{hh}$-en 
Clar, C., Prutsch, A. and Steurer, R. (2013). Barriers and guidelines for public policies on climate change adaptation: A missed opportunity of scientific knowledge-brokerage. Nat Resour Forum Natural Resources Forum, 37(1), 1-18.

Eisenack, K., Pechan, A., Moser, S. C., Hoffmann, E., Klein, R. J. T., Klein, R. J. T., Oberlack, C., ... Termeer, C. J. A. M. (January 01, 2014). Explaining and overcoming barriers to climate change adaptation. Nature Climate Change, 4, 10, 867-872.

Ford, J. D., Berrang-Ford, L., \& Paterson, J. (2011). A systematic review of observed climate change adaptation in developed nations. Climatic Change, 106(2), 327-336.

Hamin, E. M., Gurran, N., \& Emlinger, A. M. (2014). Barriers to municipal climate adaptation: Examples from coastal Massachusetts' smaller cities and towns. Journal of the American Planning Association, 80(2), 110-122.

Hamin, E.M. and N. Gurran (2015). Climbing the Adaptation Planning Ladder: Barriers and Enablers in Municipal Planning in W. Leal Filho, ed. Handbook of Climate Change Adaptation. London: Springer. Holdren, J. (2008). "Science and Technology for sustainable well-being", Science, 319:424-434.

Intergovernmental Panel on Climate Change. (2007). Climate change 2007: Synthesis report (Contribution of Working Group I, II and III to the Fourth Assessment Report of the Intergovernmental Panel on Climate Change [Core writing team: R. K. Pachauri, A. Resising (Eds.)]). Geneva, Switzerland: Author.

Measham T, Preston B, Smith T, Brooke C, Gorddard R, Withycombe G et al. (2011) Adapting to climate change through local municipal planning: barriers and challenges. Mitigation and Adaptation Strategies for Global Change 16, 889-909.

Moser, S. C., \& Boykoff, M. ed. (2013). Successful Adaptation to Climate Change - Linking Science and Policy in a Rapidly Changing World. London and New York: Routledge.

Moser, S. C., \& Ekstrom, J. A. (2010). A framework to diagnose barriers to climate change adaptation. Proceedings of the National Academy of Sciences, 107(51), 22026-22031. 
Moser, S., Kasperson, R., Yohe, G. and Agyman, J. (2008). Adaptation to Climate Change in the Northeast United States: opportunities, processes, constraints. Mitig Adapt Strat Glob Change 13: 643-659.

Preston, B. L., Westaway, R. M., \& Yuen, E. J. (2011). Climate adaptation planning in practice: An evaluation of adaptation plans from three developed nations. Mitigation and Adaptation Strategies for Global Change, 16(4), 407-438.

Ray, A. D. \& Grannis, J. (2015). From Planning to Action: Implementation of State Climate Change Adaptation Plans. Michigan Journal of Sustainability, Volume 3, Spring.

Ryan, R. (2006). Comparing the attitudes of local residents, planners, and developers about preserving rural character in New England. Landscape and Urban Planning 75, 5-22.

Schechtman, J., \& Brady, M. (2013). Cost-efficient climate change adaptation in the North Atlantic. National Oceanic and Atmospheric Administration (NOAA), Sea Grant.

Shi L, Chu E \& Debats J (2015) Explaining Progress in Climate Adaptation Planning Across 156 U.S. Municipalities, Journal of the American Planning Association, 81:3, 191-202.

Shi, L., Debats, J., Chu, E., Anguelovski, I., Aylett, A., Goh, K., Schenk, T., ... Van, D. S. D. (January 27, 2016). Roadmap towards justice in urban climate adaptation research. Nature Climate Change, 6, 2, 131-137.

Swart R, Biesbroeck R, Binnerup S et al (2009) Europe adapts to climate change: comparing national adaptation strategies. Partnership for European Environmental Research, Helsinki.

Tribbia, J. and Moser, S. (2008). More than information: what coastal managers need to plan for climate change. Environmental Science and Policy, pp. 315-328. 
